\title{
City Mascot as A Supporting Force in City Imaging
}

\author{
Paku Kusuma ${ }^{1}$, Didit Widiatmoko² \\ ${ }^{1}$ Visual Communication Design, Telkom University Bandung, Indonesia \\ ${ }^{2}$ Visual Communication Design, Telkom University Bandung, Indonesia \\ does.sense@gmail.com (Paku Kusuma)1, widiatmokodw@gmail.com (Didit Widiatmoko)²
}

\begin{abstract}
The discourse about mascot in Indonesia nowadays starts emerging on the discussion among visual communication designer community as well as creative industry practicioners. Moreover since its existence is not only applied on sport event, but also expands to various field, whether as business promotion, imaging efforts, to campaign forms. One of the interesting discourses is that for the first time mascot is inaugurated by city government as a part of identity of a city in Indonesia, namely Malang, in an effort to promote the city's tourism and as a differentiate feature with other cities. This adaptation refers to the cities in Japan which had previously use the power of mascot as a supporting power in developing its potential, like Perfecture Kumamoto with its mascot, Kumamon. Then how does mascot become the ambassador of a city's image related with culture, resources, as well as infrastructure facility of a city? The goal of this research is to give sufficient understanding about city mascot existence while showing its importance for visual communication desainers and creative industry practitioners in creating a work. While the approach used in this research is through social research, considering how close the topic discussed with local tradition and culture. The approach was chosen to find mascot's positioning in its relation with city image potential, thus the benefit of its use for local government can be seen. The study was done in Malang, Surabaya, and Kumamoto Perfecture through deep direct observation, interview, as well as literature research. The benefit of learning the process of this research result is hoped to be used as a reference and model in the application of mascot contest and other intellectual property in the future. Also to strengthen the base in mascot creation which indeed should be able to accomodate what it represents.
\end{abstract}

Keywords Conceptual mascot, city mascot, city image

\section{Introduction}

Since the introduction of regional autonomy policy in 2004, each provincial government in Indonesia has more authority in regulating its territory in terms of local regulation policy, Regional Development Budget management, as well as public interest. This policy also affects cities and districts in the management of their territory. This indirectly changes the pattern of policies in the local establishment and development efforts, especially in terms of local revenue and financial management. Probably because of this change, at the end of 2016, the city of Malang excitedly inaugurated its city mascot named Osi and Ji as one of its icons, coincided with the city's 103rd anniversary. This mascot was made by Papang Jakfar after going through a series of contest stages including presentation by hundreds of participants.

Osi and Ji mascot is an effort to improve the image of Malang city so it is expected to give positive impact in various fields such as public relations, tourism, regional promotion, and urban planning. In its website (osidanji.com) which is an activation channel, it is said that the presence of Osi and Ji is an asset of Malang city which is expected to be the pride of its city residents. Papang Jakfar's intellectual work is the result of a good quadrahelix collaboration after a case study on the drama during Asian Games mascot creation named Drawa which was quite controversial. Even further, it is said that Osi and Ji mascot exists as public rights that can be used by the citizens even for commercial purposes, with reference to the provided reproduction references and guidelines.

Before Osi and Ji were inaugurated, a year previously, Surabaya which is still in the same province with Malang, also held a city mascot contest. Surabaya mascot contest in its mandatory referred to the form of the city's icons, namely Sura and Baya which have been established and also made into landmark in front of Surabaya zoo. Nevertheless, after a series of the contest process the completed Surabaya city's mascot was not directly inaugurated, thus its existence was little known. Both cities are pioneers of city mascot and known to compete in any case, especially football, but the two mascots created have similarities, namely the result of collaboration between associations or 
professional institutions in the field of creative, academicians, local government and the community. Both of the mascots also have a similar purpose that is to promote and improve the image of their respective regions.

City image is a distinctive impression attached to a city that represents it to its people and visitors. On the Dictionary of Bahasa Indonesia, the word "image" defined as a look, figure, or description. According to Kevin Lynch in the book Image of the City, it is revealed that there are five elements of city's image forming, physically the path where there is movement from observers in the area in the form of roads, sidewalks, railroads, edge, borderline area that can be marked with river, gate, wall, bridge or coastline area; district, a region that has similarities, this characteristic can be felt and compared with other areas by observers such as cyber villages, color villages, weaving producers village, etc; nodes are strategic locations where observers can enter, pause and orientate activities around them, it may be in the form of crossroads, squares, stations, terminals, airports where there are meetings between one activity and another; and landmarks, usually in the form of the work of human hands such as monumental objects, markers, sculptures, skyscrapers, large billboards or vital objects in the city.

Those five elements according to Kevin Lynch represent the taste of an area and provide a strong image of a city, and among the five elements, landmark is an external element of intellectual property result that stands out visually and differently because it has meaning for the whole city. Further, landmark is often used as an orientation reference by observers because of its clear identity and strength in shaping the environmental image. A prominent and unforgettable impression for vision until it pervades into the concept of subjectivity and identity. Furthermore, according to Lynch, this environmental image is the result of a two-way process between the observer and the observed object, also called the impression or perception between the observer towards the scope of his observation. A variety of city mascots in Japan that we met when visited the country also originally started from a summary of the results of the community's observation power towards the identity of the city that became the source of the creator's idea. Qualified and well analyzed observation power plus the ability to create are finally able to produce responsible work, even the work is able to bring change.

\section{Method}

The conceptual idea of mascot as a research material is basically one of the methods of art and design work that can be implied through theoretical approach of cultural studies. This research is to present data and process of works creation, ranging from understanding the term, word definition, the process of extracting ideas, data processing to the creation process. Mascot as part of the communication element is presented objectively in this conceptual scientific research of mascot, although we realize there are still many shortcomings contained in this research. Therefore, it is expected that critics and suggestions from all parties in developing the conceptual process of the mascot to be improved in the future. We would also thank all the parties who have supported this research process.

City mascot that contributes in building city's image at the time of its visual formation must originate from the understanding of its identity to obtain perception that conform with its representation. Further, in its understanding, it should be underlined that city's iamge and city's identity are two different things. This identity is closely related to the historical rhythm of an area that has undergone a long process to form the city's identity or the characteristics of its citizens, whereas this can not be created instantly like building the city's image itself. City's identity itself according to Lynch: "... not in the sense of the likeness of an object with another, but rather refers to the meaning of individuality that reflects its difference with other objects and its recognition as its own entity" (Lynch 1960), further it is expressed: "... city's identity is a mental image formed from the biological rhythm of a place and space that reflects the sense of time, deeply rooted from within through socio-economic-cultural society of the city itself "(Lynch 1972). Identity is a process and not an invented object that can be engineered. If the identity is understood only as partial objects and icons were separated from the context of the space in which they were originated, then the result is only a mechanical reproduction of identity formation in the past (Purwanto 2001: 89). Subjectivity and identity of things are interrelated and almost inseparable, where the understanding of identity is about the similarities and differences of personal and social matters. Subjectivity and identity are typical cultural products that are contingent, mean that they are completely social products and can not "exist" outside the cultural representation and acculturation.

Identity understanding becomes very significant when we discuss about the formation pattern of a city mascot which can represent the image of the city itself. It also reinforces the existence of the mascot inthe community to the extent of having the relation of the mascot with the community to have proximity, because sometimes identity maker factors revealed are very unique and philosophical that are very different from what appears physically. In an effort to uncover the uniqueness of identity to strengthen the existence position of a city mascot, there are three stages passed, namely describing, analyzing and interpreting. Describing is defined as an activity to give a verbal explanation of something; to illustrate a verbal representation. Describing something takes skill and it is imperative to fully describe the results of all backgrounds observation, even the history of a city founding although it takes quite a long time. This skill will not be sharpened if it is not done continuously.

The analysis stage is the intellectual activity to comprehend a matter (object) thoroughly first by looking at the components or parts in detail. "Analyze" is a verb whose activity is done by dissecting each piece of information and highlighting the details of each section, then sorting out its importance to understand it more closely. The end of the analysis stage is finding a hypothesis or initial conclusion 
that can be used in interpreting a problem. Interpreting is done after the identification stage is completed, this activity is done to reveal the deeper meaning of a text (phenomenon). Interpretation can be done in several ways of approach, but it would be better to describe the meaning contained first, interpret the statement, then interpret the meaning. The interpretation stage attempts to find the deepest meaning can be seen in Kundo Koyama's Kumamon mascot, which he takes the form of a bear while in the territory itself is absolutely not a habitat for bear. The deepest meaning of this interpretation effort becomes an important point in hermeneutics discussion by Paul Ricoeur, whose thought invites the reader, the viewer, the observer of a text to give the text its own opportunity to uncover its deepest meaning. Ricoeur assumes there are no universal rules for interpretation, yet there are sometimes certain opposing rules. So interpreting activity is not a reconstruction of meaning, rather an intellectual activity that is rich of creativity. This is especially important when artists, designers or creative workers are faced with the problem of understanding the form and making the foundation of perception.

We can not deny, that a mascot is first seen or assessed through its physical appearance then the observer will perceive its value basis and visual strength. Perception is a sensory representation of external structural features of objects and processes of the material world which directly affect sensory organs (Yongky Safanayong, 2006: 36). Everyone has a perception of physical appearance. People often give a certain meaning to the physical characteristics, the shape of organ, skin color, hairstyle, and the clothes of a mascot.

\section{Discussion}

\subsection{Conceptual Mascot}

Since the word mascot was adopted in Dictionary of Bahasa Indonesia in 1983 and was first used commercially and inaugurated in 1985 for Dunia Fantasi (Indonesia's famous theme park located in Jakarta), the development seems stagnant. There are many factors that are percieved making the development not as fast as in other countries. Local cultural factors and authoritarian powers are considered to be the obstacles at the time. After the collapse of the New Order regime in 1998 and the beginning of the creative economy era in 2004, the existence of mascots began to experience changes mainly due to the rise of the number of universities which open the interest for scientific Visual Communication Design major. This rise was encouraged by community's emerging interest as well as the demand for working force in the field from the industry which is quite high. In the end it boosted the number of academicians and intellectuals of the field. In its development until now, the field seems to have shifted to be in charge for the creative process of mascot. The term mascot in the Dictionary of Bahasa Indonesia is also depicted as covering anything that is used to represent a general public group, such as school, professional sports team, community, military unit, or brand name, through a certain form of representation.
Mascots can be regarded as a media that has the credibility to deliver a message more personally while increasing awareness from the audience. Its medium form is not static (flexible) which becomes a distinct advantage of mascot, especially visually mascot is pleasant to see. As a medium that has a high flexibility, the physical shape of a mascot greatly influences the design pattern and the power of messaging. When viewed from the basic physical form, mascot can be divided into 3 forms of categories, namely: shape objects, animal forms and fictional figures.

Choosing the form of a mascot can be more easily done by considering these factors:

\section{Expression}

Many people assume that the most expressive non-verbal behavior is facial expression, although the mouth does not speak (Mulyana, 2007: 372). Expression is a major non-verbal behavior that shows one's emotional state. There are some emotional states communicated through facial expressions, that seem to be universally understood: happiness, sadness, fear, anger, disgust and interest. It must be kept in mind that the type and character of a mascot to be accentuated must have a broad view of the future and about the goal by applying such expression.

\section{Behavior}

Behavior is a person's actions, which can ultimately characterize an illustration of a person's identity to a particular group of people. Behavior is also found in all living things, both animals and plants, and each has different behavior and treatment. The existence of some behaviors described in the figure of a mascot will also manifest the representation of the entity's appearance.

\section{Identity}

Identity is a form of imaginative identification with the symbol of regional discourse. Not just political formation, but also a cultural representation system where identity is continually reproduced as a discursive act. The symbolic and discursive dimensions of identity continue to tell and create ideas about origins, continuity, and traditions. Identity is our identification with the representation of shared experience and history as told in fairy tales, literature, popular culture, and media.

\subsection{The Study of Kumamoto Perfecture's Mascot}

The mascot of Kumamoto prefecture in Kyushu island named Kumamon becomes very popular in Japan and is considered as the most loved mascot by Japanese through the results of an online poll. Kumamon began to be embodied and introduced to its use on March 12, 2010. The creative work by Kundo Koyama, who works as a journalist and scriptwriter, takes the original idea in the form a small form of bear, although there is no actual bear in Kumamoto area. However, Japanese is known is into anything funny and cute or in local term, "kawai", including the teddy bear brought by American soldiers in the post-World War II recovery period and this eventually becomes the characteristic of today's 
modern Japanese society. The background story about the black bear pup who was originally going to be hunted by 26th American president, Theodore Rosevelt, became the source of ideas in the development of writings or depictions that color the city's mascot character. The uniqueness of a simple visual formation pattern with the overall use of curved lines of elliptical and circular shapes except slightly on the underside of the flat stomach and legs, makes it easy to reproduce to become images that are often made by children as a school task. Kundo Koyama himself considers the children in the city of Kumamoto, Kyushu, as the source of important element which became his idea consideration in forming the mascot's visual character; because anyway man is a homo ludens, who basically love to play.

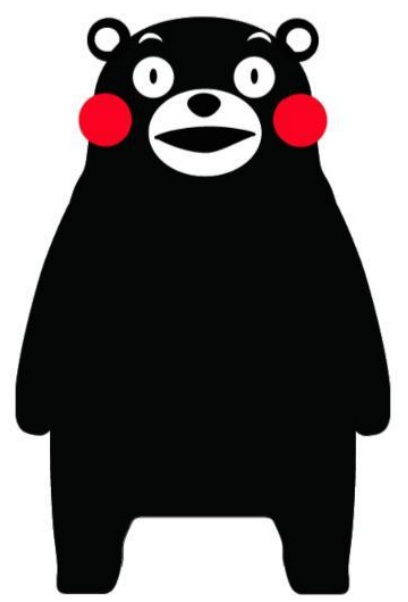

Figure 1. Kumamoto Prefecture Mascot, Kumamon. By Kundo Koyama

Kumamon originates from the Japanese word "kuma" which means bear and "mono" which, in local dialect, means people. The Kanji for the word "kuma" in Kumamon resembles the Kanji in writing the word Kumamoto prefecture. The mascot's wide eyes and white mouth look contrast with its red blushing cheeks. This uniqueness is increasingly popular after the local government also promoted it on various media assisted by local communities.

Kumamon's popularity has had its own impact, such as, with the sale of merchandise products up to about 29.3 billion Yen in the first year of its promotion into the local budget flow. This result closely approached the total income of Kumamoto Prefecture which is famous for its agricultural products. Local government also involves the mascot of this prefecture into a number of activities or tour promotions in Japan or abroad. Kundo Koyama as the creator of Kumamon along with the local government allowed everyone to use this illustration freely without obligation to pay any fees even for trademarks usage. Recently, Kumamon has become an inseparable part of Kumamoto prefectural society, become a common pride, color the city, made tourist region splendor, as well as increased the creativity of its community.

\subsection{The study of Malang City Mascot}

The contest to create a mascot for Malang city was initiated by Graphic Design Association of Indonesia (ADGI) chapter Malang after learning that the promotion program of Beautiful Malang by the city government did not get good response from the community. After receiving a positive response from academicians and local government, the contest stage was started by collecting portfolios from the participants. The contest committee distributed contest information to various regions to collect a total of 102 portfolios of potential participants. After being selected through work ability background checking as well as work experience in the last two years, 20 candidates were finally invited to Malang for a briefing delivered by responsible local working unit or SKPD as well as handing out of the material about Malang identity. The participants then performed the study independently and made the work along with the template until the works collecting deadline. After the works were collected, concept presentation stage was undergone by each participant. Finally, through the highest assessment, Osi and Ji mascot created by Papang Jakfar was inaugurated as the winner.

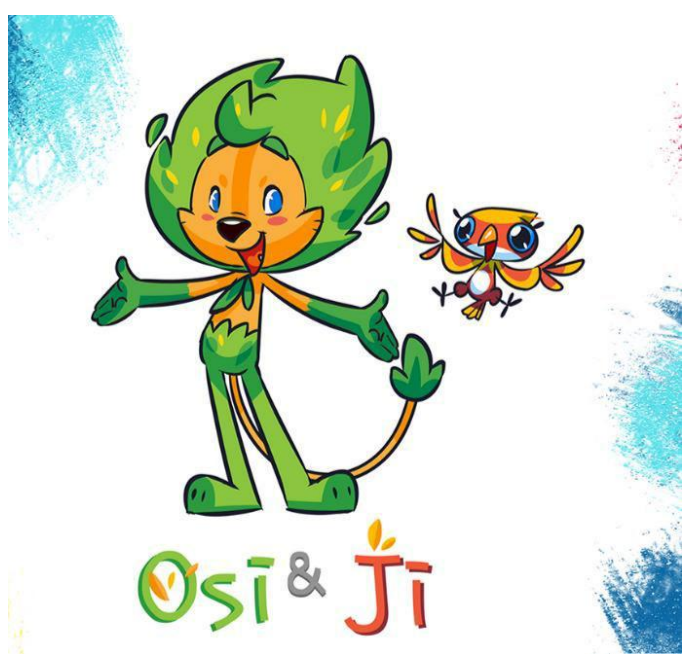

Figure 2. Malang City Mascot, Osi and Ji. By Papang Jakfar

Osi and Ji adopted the side of very rich local history and wealth as a main source of ideas, in order to represent Malang as a city of education, a beautiful city, as well as the city's local language of Walikan, and lion and Manyar bird. The naming of Osi and Ji alone has shown strong identity power as a candidate for Malang city mascot which will be familiar to its society, the name Osi which is given to the lion figure was derived from the word 'iso' which means 'able' and used language of Walikan Ngalam pattern. While Ji for the Manyar bird, was derived from the word 'siji' which means 'one'. Thus, the name of Osi and Ji means iso dadi siji (able to be one [united]). Besides implied the meaning of unity (harmony of Malang citizens), it also expressed the desire of Malang people to always make their region to be number one and put community interests first. From this stage, finally, the usage of Osi and Ji illustration is opened as wide as possible for creative citizens of Malang to be utilized in any form except as a trademark.

Like Kumamon, lion's habitat does not exist in the island of Java, but there are artifacts depicting lion statue in Kidal temple. Notably during the Dutch occupation, the symbol of 
lion had been displayed very prominently in various corners of the city which were built by an architect named Thomas Karsten. Recently, in addition to be the symbol of Malang's pride soccer team, Arema, and its supporters which are known as Ongis Nade (singo edan or crazy lion) lion has also become part of the identity of Malang citizens. Green color as the dominant color of Osi symbolizes the beauty of Malang (color that symbolizes the cool temperature and lush trees in Malang). However this color was once

questioned and protested by some people who believe that their pride color is blue while the green color belongs to other area (Surabaya), because of their lack of knowledge about their identity. The history of green color in Malang can be proved in the statute of local government which explained that the symbol of city government is dominated by green color, while dominant blue color is owned by the government of Surabaya city. The dominant green is then balanced with the yellow-orange color (warm color) for the face and chest of Osi, and also for Ji which represents typical color of Manyar birds. Manyar Bird (Ploceus Manyar) is a typical fauna of Malang based on Governor Decree number $5225 / 16774 / 032 / 1996$. The tie (hasduk) wore by Osi is a symbol of education \& scout.

\subsection{The Study of Surabaya City Mascot}

Surabaya City mascots, Cak Sura and Cak Baya created by I Gusti Agung Rangga Lawe, a graduate of Visual Communication Design from Telkom University, were originated from a contest of Surabaya city mascot "Kinetic" in 2015. This contest was intended to reproduce the previous icon of Surabaya into a a fresher packaging to assist in the socialization of local government programs. The identity represented in the formation of this city mascot is an iconic form that marks the area in front of Surabaya zoo in the form of shark (Sura) and crocodile (Baya). The shape was described by historians as a representation of important events that marked the birth of Surabaya city through the research on the statue of Jokodolog. Historians revealed that the name Surabaya itself, which comes from the word "sura ing bhaya" meaning "courage to face danger", was derived from an important event in the history of Nusantara archipelago when Mongol troops who came through the sea were defeated by Javanese forces led by Raden Wijaya on May, 31st 1293. The date was then determined as the anniversary of Surabaya through the Decision Letter no. 64 / WK / 75 about the determination of the anniversary of Surabaya.

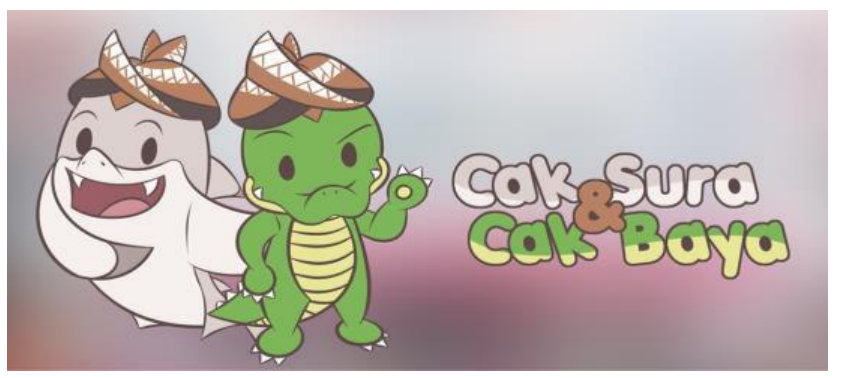

Figure 3. Surabaya City Mascots, Cak Sura and Cak Baya. By I Gusti Agung Rangga Lawe.
Cak Sura's color is dominated by ash-white, while the green-yellow as the color of Cak Baya has a resemblance to the original physical color of the animal, crocodile. The created characters are the adaptation result of history and famous folktale in the community about the origins of $\mathrm{Su}$ rabaya city which tells about the battle between sharks and crocodiles in the estuary of a river. Both animals were told as equally strong and then finally made a mutual agreement and became friends. The character of Cak Sura was illustrated as a wise animal and uphold ethic, in contrast to Cak Baya character who speaks spontaneously, straight forwardly and decisively. Both of these characters use the same headdress (udeng) shaped like blangkon (traditional Javanese headdress worn by men) as a form of mutual agreement, with edge batik motifs of white modang with three levels black and sloping poncot, the headdress usually worn by men in Surabaya and became the hallmark of fashion of the region. Nickname 'Cak' is a typical greeting for male Surabaya residents which represent the intimacy and openness of the community to guests/visitors.

Cak Sura's color is dominated by ash-white, while the green-yellow as the color of Cak Baya has a resemblance to the original physical color of the animal, crocodile. The created characters are the adaptation result of history and famous folktale in the community about the origins of $\mathrm{Su}$ rabaya city which tells about the battle between sharks and crocodiles in the estuary of a river. Both animals were told as equally strong and then finally made a mutual agreement and became friends. The character of Cak Sura was illustrated as a wise animal and uphold ethic, in contrast to Cak Baya character who speaks spontaneously, straight forwardly and decisively. Both of these characters use the same headdress (udeng) shaped like blangkon (traditional Javanese headdress worn by men) as a form of mutual agreement, with edge batik motifs of white modang with three levels black and sloping poncot, the headdress usually worn by men in Surabaya and became the hallmark of fashion of the region. Nickname 'Cak' is a typical greeting for male Surabaya residents which represent the intimacy and openness of the community to guests/visitors.

\section{Analysis}

Observing the visual works of the study on the three city mascots above, it can be seen that the path of the creation process requires design thinking ability that can only be mastered by those who are intensely work in the field and have understood the basis in the process of creating along with the ability to habituate design problems solving. The necessity to understand the identity background of the represented entity, to translate symbols, to understand the text and to interpret the social sphere before entering the process of creating shows that the intellectual factor is very dominant in the process of creating a city mascot, therefore, it is reasonable that this mascot works are considered as intellectual property and must be patented. 
According to Ricoeur, there are three steps of understanding. First, the symbolic step, or an understanding from symbol to symbol. The second step is giving meaning through the symbols and careful 'exploration' of the meaning. The third step is the actual philosophical step, namely thinking by utilizing the symbol as a starting point. A visually presented work such as a city mascot is basically an effort to expose all the existing potential and is already a part of the local entity, thus the process of understanding the identity and meaning of symbols becomes crucial.

Table 1. Comparison of the mascot character of Kumamoto prefecture,

\begin{tabular}{|c|c|}
\hline \multicolumn{2}{|r|}{ Malang city and Surabaya city } \\
\hline Mascot & Analysis \\
\hline \multirow{7}{*}{$\begin{array}{l}\text { Kumamon } \\
\text { Citi Mas- } \\
\text { cot } \\
\text { (Kundo } \\
\text { Koyama) }\end{array}$} & Black bear figure (Animal). \\
\hline & Keywords: Agricultural Tourism, Kyushu island, Kawaii. \\
\hline & Purpose: tourism promotion and the inauguration of the new \\
\hline & Shinkasen express rail line in Kyushu. \\
\hline & Dominated by black color. \\
\hline & $\begin{array}{l}\text { The dominant features are of curved and elliptical lines, } \\
\text { simple display, flat expression, easy to reproduce and repli- } \\
\text { cate. }\end{array}$ \\
\hline & $\begin{array}{l}\text { Selected through closed contest. Winner was determined by } \\
\text { online polls by people who are technology literate. }\end{array}$ \\
\hline \multirow{9}{*}{$\begin{array}{l}\text { Osi and Ji } \\
\text { Malang } \\
\text { City Mas- } \\
\text { cot (Pa- } \\
\text { pang Jak- } \\
\text { far) }\end{array}$} & Lions and birds. \\
\hline & Keywords: education city, beautiful city, Lion and Manyar \\
\hline & birds, Walikan as Malang's local language. \\
\hline & Purpose: Anniversary celebration, tourism promotion and \\
\hline & local government ambassador. \\
\hline & $\begin{array}{l}\text { Dominated by green, yellow-orange. } \\
\text { The dominant features are the dynamic shane emphasize on }\end{array}$ \\
\hline & natural elements of leaves, with cheerful expression. \\
\hline & $\begin{array}{l}\text { The contest was done through the selection process of works } \\
\text { by the contest committee and juries. }\end{array}$ \\
\hline & $\begin{array}{l}\text { Still in the activation process, the results have not been } \\
\text { calculated yet. }\end{array}$ \\
\hline \multirow{6}{*}{$\begin{array}{l}\text { Cak Sura } \\
\text { and Cak } \\
\text { Baya } \\
\text { Surabaya } \\
\text { City Mas- } \\
\text { cot (Agung } \\
\text { Rangga) }\end{array}$} & Shark and crocodile figures (Animal). \\
\hline & Keywords: Surabaya city icons and the richness of \\
\hline & Purpose: city icon reproduction, local government \\
\hline & $\begin{array}{l}\text { programs socialization and promotion. } \\
\text { Dominated by gray and green. }\end{array}$ \\
\hline & $\begin{array}{l}\text { The dominant features are its dynamic shapes with } \\
\text { typical headdress which shows locality elements. } \\
\text { Selected through open contest and the winner was } \\
\text { determined through online polls. }\end{array}$ \\
\hline & $\begin{array}{l}\text { Not yet well applied, still for ceremonial purposes } \\
\text { only. The result of the profit has not been calculated. }\end{array}$ \\
\hline
\end{tabular}

The phenomenon that emerges nowadays shows that the city mascot created through a good understanding process on the identity, along with in-depth research always has a unique position. In addition as a promotional tourism ambassador, socialization of government programs, mascot also becomes a part in the point of view of its environment image which further makes the observer possess ownership rights towards the mascot. The resulted mascots did not necessarily take the physical source of ideas from what is manifested and clearly appeared in the eyes but sometimes more deeply toward the sense owned by the citizen as well as the percep- tion of the surrounding; and that what is called identity. According to Lynch, that identity is a process and not an invented object that can be engineered

\section{Results}

The existence of mascot as an effort to support a city imaging requires the existence of research to illustrate visual identity of which expected to have the most optimal impact. If possible then, there should be an active participation/collaboration of four elements, namely the government, academicians, industry and community practitioners (quadruple helix), because without the role of one of those elements, imbalance will appear, thus ignite controversy and conflict. The impression will appear as forced and even may change visual form of the mascot that is supposed to be able to represent any message to be delivered; to become merely a form without any deep meaning and far from the love of the community it represents. The success of a city mascot in improving the image of a city leading to an increase in people's income, that may be acquired if all the elements also cooperate in its activation, especially in social networking media.

Another interesting result to be exposed is that the field of mascot creation discussed here is still very rarely occupied and not considered important although often used as a reference material in learning process in the university, especially in design majors. This is very strange considering how big the benefits that can be obtained by all parties, as well public interest that was very large in supporting the creation of city mascot in each area of research, especially with the infiltration of foreign cultural elements that enrich point of view and thought in wider community.

\section{Conclusion}

According to Ricoeur, there are three steps of understanding, namely symbolic step, or understanding from symbol to symbol. The second step is the giving of meaning through symbols and the 'digging' meaning. The third step is the actual philosophical step, namely thinking by using the symbol as a starting point. A visually presented work such as a city mascot is basically an effort to expose all the existing potential and is already a part of the local entity, thus the process of understanding the identity and meaning of symbols becomes crucial. Manifestation of this understanding can bridge the birth of amazing city mascot.

\section{REFERENCES}

[1] Baran, Stanley J. 2012, Pengantar Komunikasi Massa. Penerbit Erlangga, Jakarta

[2] Barker, Chris. 2005, Cultural Studies, Teori dan Praktik. PT. Bentang Pustaka, Yogyakarta 
[3] Jenks, Chris. 2013, Culture. Studi Kebudayaan. Pustaka Pelajar, Yogyakarta

[4] Lynch, Kevin. 1960, The Image Of The City. The MIT Press, Cambridge, Massachusetts

[5] Lynch, Kevin. 1972, What time is this Place? The MIT Press, Cambridge, Massachusetts

[6] Lynch, Kevin. 1995, City Sense and City Design. The MIT Press, Cambridge, Massachusetts

[7] Marianto, Dwi. 2015, Art \& Levitation: Seni dalam Cakrawala Quantum. Pohon Cahaya, Yogyakarta

[8] Neuman, W. Lawrence. 2015, Metode Penelitian Sosial: Pendekatan Kualitatif dan Kuantitatif. PT. Indeks, Jakarta

[9] Panofsky, Erwin. 1982, Meaning in The Visual Arts. The University of Chicago Press, Chicago

[10] Ricoeur, Paul. 1981. Hermeneutics \& The Human Sciences. The Press Syndicate of The University of Cambridge, New York

[11] Safanayong, Yongky. 2006. Desain Komunikasi Visual Terpadu. Arte Intermedia, Jakarta

[12] www.osidanji.com

[13] www.agungrangga.com

[14] www.akibanation.com/kumamon-beruang-jepang-terpopoler I

[15] http://www.bbc.com/future/story/20160719-meet-japans-ku mamon-the-bear-who-earns-billions

[16] Wawancara Dadik Wahyu Chang, Utero Advertising, tanggal 13 Mei 2017

[17] Wawancara Papang Jakfar, Papang Kingdom, tanggal 14 Mei 2017

[18] Wawancara Pandu Zanuar, Bappeda Kota Malang, tanggal 15 Mei 2017 